\title{
A Conceptual Framework: Creating Socially Just Schools for Students with Emotional and Behavioral Disabilities
}

\author{
Kirstine J. Melloy, ${ }^{1, *} \&$ Francie R. Murry ${ }^{1}$ \\ ${ }^{1}$ School of Special Education, University of Northern Colorado, Greeley, Colorado, USA \\ *Correspondence: School of Special Education, University of Northern Colorado, Greeley, CO., USA. Tel: \\ 1-970-351-3553. E-mail: kristine.melloy@unco.edu
}

Received: September 20, 2019

Accepted: October 16, 2019 Online Published: October 25, 2019

doi:10.5430/wje.v9n5p113

URL: https://doi.org/10.5430/wje.v9n5p113

\begin{abstract}
Students with emotional and behavioral disabilities (EBD) are among the most marginalized group of students in our schools. In essence, students with EBD are often denied their civil right to a free and appropriate public education (FAPE) which is a social justice issue. Teachers who become social justice allies are more likely to create a socially just school when they promote the implementation of multi-tiered systems of support (MTSS) through evidence-based practices (EBP) for positive behavior interventions and supports through a social justice lens. Implementing these interventions while being social justice allies in socially just schools offer the best opportunity for students with EBD to receive an equitable and socially just education in schools thereby achieving social justice regarding their civil right to a FAPE.
\end{abstract}

Keywords: students with emotional and behavioral disabilities, multi-tiered systems of support (MTSS), positive behavior interventions and supports, social jus

\section{Introduction}

Although the latest report from the United States (US) Department of Education (2016a) revealed that nearly half of all students with emotional and behavioral disabilities (EBD) receive the majority of their education in general education classrooms they are among the most marginalized group of students in US schools (Education Week, 2018; Santo, Ferguson, \& Trippel, 2010; OSEP, 2016). Various data sources show clearly that students with EBD are disproportionately impacted by practices that deny them their civil right to a free appropriate public education (FAPE) as guaranteed by the Individuals with Disabilities Education Act 2004 (IDEA, 2004). These practices include being suspended in-school and out-of-school, being expelled from school, and being placed in seclusion or being physically restrained at rates that are significantly higher than those experienced by students without disabilities (Brobbey, 2018; Ennis \& Katsiyannis, 2018; U.S. Department of Education, 2016b; U.S. Department of Education Office for Civil Rights, 2016). These statistics beg the question; 'Are students with EBD receiving the services necessary for them to stay within inclusive settings?'

The potential for additional adverse outcomes occurs for students with EBD because they are the students who are the most likely to have higher rates of chronic absenteeism from school when compared to students without disabilities (Office of Civil Rights, 2016). Rates of absenteeism and lack of future college and career readiness increase the opportunity gap for access to high-rigor courses. Due to this reason, students with EBD are unlikely to be enrolled in physics, calculus, chemistry, and algebra (U.S. Department of Education Office for Civil Rights, 2016). Not having taken college and career-ready courses is a challenge for students with EBD to enter from high school into the college and career pipelines. This lack of readiness can relegate students to low-level employment opportunities no matter their intellectual abilities.

Students with EBD continue to experience educational disparities even though their right to access equitable schools have a strong foundation in several policies that have been adopted worldwide, specifically regarding students with disabilities. The Salamanca Statement was a policy signed by representatives of 92 countries, declaring that it is the right of all students to be educated in the general education setting (UNESCO, 1994). Even earlier, in 1948, the United Nations developed the Universal Declaration of Human Rights \& the Convention on the Rights of the Child, 
to confirm that children have a fundamental human right to quality education and to be treated with dignity.

These historical policies set the stage for lawmakers in the United States to create the foundation for the inclusive education of students with disabilities. The Individuals with Disabilities Education Act of 2004 (IDEA, 2004) ensures that all children with disabilities are entitled to a free appropriate public education (FAPE) to meet their unique needs and prepare them for further education, employment, and independent living. IDEA is a federal legislative act that mandated schools in the U.S. to ensure every student with a disability has a FAPE (\$300.101) and an educational experience based on the concept of equity. This legislation does not translate into meaning that students with EBD automatically receive $100 \%$ of their education in the general education setting. The FAPE concept in IDEA focuses on the provision of access, opportunity, and the rights of students with EBD to an equitable, inclusive education included in the scope of socially just education. The purpose of this article is to present a conceptual framework that outlines ways in which educators can create socially just schools for students with EBD. First, socially just schools will be defined. Second, a description is offered of how educators using the implementation suggestions for multi-tiered systems of support with a social justice perspective can act as social justice allies for students with EBD.

Social justice is difficult to define, as there are numerous ways to approach its implementation. The ability to implement it into schools that want to remain with a traditional approach of the 'principal to the teacher, teacher to the student' empowerment structure may not benefit as fully as educational personnel who are ready and want to challenge structural injustice and become a socially just school.

\section{Definition of Socially Just Schools}

The foundation for socially just schools lies in how and to what degree the implementation of social justice occurs. According to McDermott (2017), socially just schools examine their organization to identify who wields power concerning individuals who are included in crucial decision-making (i.e., by whom, why, and by what authority). For example, social justice educational decision-makers consider the impact of distribution and allocation of finances with regard to the needs and future potentials of all students.

Socially just schools do not treat students equally; they treat students equitably. To treat students equally would be unjust and violate the IDEA mandate of specially designed instruction (\$300.39). Instead, in a socially just school, equitable access is accomplished to meet the unique needs of a student with EBD based on their Individualized Education Plan (IEP §300.320; IDEA, 2004; McIntosh, Girvan, Horner, Smolkowski, \& Sugai, 2018). The creation of a student's IEP by a team depicts one of the most evident characteristics of a socially just school where the adults and students share power that results in respect and dignity (McDermott, 2017; Scott, 2017). The creation of an individualized educational plan executed within a socially just school embraces the fundamental concepts found in Smyth's (2004) description of social justice, "Articulating the student's purposes, advancing a concern for social injustice, continually (re)focusing around learning, pursuing a culture of innovation, enacting democratic forms of practice, being community-minded, displaying educative forms of leadership, and engaging in critical literacies" ( $p$. 19). In socially just schools, plans are made with and for students to experience academic, behavioral, and social-emotional achievement.

As educators examine their organization, they become aware of how students with EBD in their schools are marginalized and denied their civil rights to FAPE, and recognize the need to change how they approach, react attitudinally, and participate in the creation of educational environments. The changes involve shifting to a school-wide perspective of social justice and educators who act in the role of social justice allies. Educators need to work toward the elimination of segregated educational programs and find multiple ways to provide opportunities for inclusive practices.

\section{Educators as Social Justice Allies}

Educators can promote social justice for students with EBD by becoming social justice allies and creating schools that promote multi-tiered systems of support (MTSS) (McIntosh \& Goodman, 2016). As educational needs and student demographics shift toward more robust challenges, educational personnel need the knowledge, skills, and dispositions, to successfully work with the population of diverse students, including students with EBD. Educators, especially special educators, understand the need to promote a blended relationship between behaviors and academics and to identify the unique needs of students with EBD. This understanding puts educators in an excellent position to promote program and policy consideration founded on the principles of social justice. Allies who want to promote this blended work between special and general education must become or be aware of the scholarship on 
disability identification disparities which has a dual nature of both protection and stratification (Artiles, Dorn \& Bal, 2016). While identifying and developing services for students with EBD educators must test their assumptions and perceptions about students' deficits and ableism. Caution is given to allies who walk the fine line between protecting and curtailing the educational opportunities for students with special education labels.

McDermott (2017) provides a formula for becoming a social justice ally that fits educators: Dispositions + Preparation + Position $=$ A Social Justice Ally. The first element in the formula, dispositions, is confirmed by the passion educators express about educating students. The reward felt by teaching learners is one of the most common reasons educators give for entering the profession (Hong, Greene, Roberson, Francis, \& Keenan, 2018). Dispositions of effective educators provide the drive needed to engage in the second element, preparation. Being prepared to teach students requires an understanding of how to be and act strategically (Cordingley, 2015; McDermott, 2017). Effective teacher preparation programs for special education teachers provide them with the ability to plan specially designed instruction based on students' IEPs. They learn to begin with the end in mind and shape learning goals, set the criterion for student performance and create a vision for success that is purposeful and intentional (Fried \& Harper, 2017). By creating practices to unlock the potential of the students on the margins, educators build relationships that reinforce and activate students' strengths while developing the needed trust between students and educators that can elicit high intellectual and academic performance. The third element in the social justice ally formula described by McDermott (2017) is position. She described this element as the institutional sway educators possess, and the access educators have to work with a full spectrum of students from the most privileged to the most marginalized and the many intersections that entail (e.g., students with disabilities, gender, race, poverty). For example, in considering students with EBD, educators can use their position to convince others to join them in promoting social justice for students, especially about students' FAPE.

As social justice allies, educators stand up for and with those who are not as capable, so that they can stand up for themselves. In working with students with EBD, this work is crucial to developing socially just schools where students can thrive, achieve, and learn to advocate for themselves.

\section{Implementing the MTSS Framework with a Social Justice Perspective}

More than one-fourth of the states in the United States mandate that schools develop and use multi-tiered systems of support (Zirkel, 2015). Both the Every Student Succeeds Act (ESSA) and the Individuals with Disabilities Act of 2004 (IDEA) are associated with the multi-tiered systems of support. The implementation of MTSS programs are varied and evidence-based, holistic and systemic approaches with the end-goal of improving student learning and social-emotional-behavioral functioning (Avant, 2016; Colorado Department of Education, 2015; Horner, Sugai, \& Lewis, 2015; Proctor, Graves, \& Esch, 2012). See Figure 1 for a graphic depiction of the Colorado MTSS essential components. The Colorado definition of a Multi-Tiered System of Supports (MTSS) is "a prevention-based framework of team-driven data-based problem solving for improving the outcomes of every student through family, school, and community partnering and a layered continuum of evidence-based practices applied at the classroom, school, district, region, and state level." It is a system focused change approach, rather than a student change approach. 


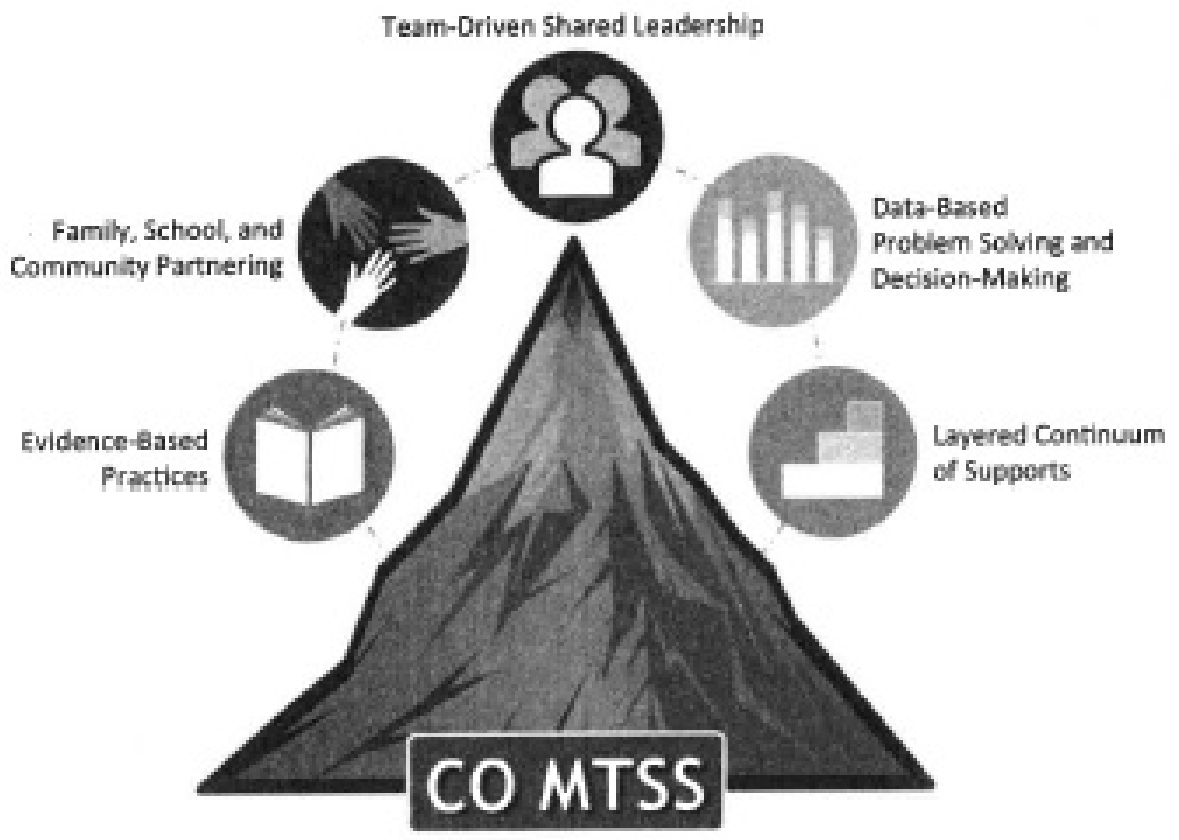

Figure 1. Colorado MTSS Essential Components

The MTSS framework is designed to serve all students. The social justice conceptual goals of including all students and eliminating the marginalization of student groups in schools, can be intentionally accomplished by implementing graduated layers of more intensive interventions, building rigorous outcomes through data-driven decisions, and collaborative partnering (Freeman et al., 2015; Preston, Wood, \& Stecker, 2016; Turse \& Albrecht, 2015). When done well using the crucial components of being proactive, rewarding students' performance, providing support for struggling students in both academic and behavior areas, MTSS embeds the social justice concept. There are calls for the need for more training for educators who are working within the MTSS tiered system of support for all students while also understanding how to recognize when students have differences that require tailored learning supports (Artiles et al., 2010; Banks \& Obiakor, 2015; Klinger \& Edwards, 2006).

A layered tiered system of approach is in more than 16,000 schools in the U.S., Australia, Canada, and Norway (McIntosh, Ty, Horner, \& Sugai, 2013). A typical graphic depiction of the layered model for these systems of support has three tiers. The tiers of instruction are represented as a pyramid with Tier 1defined as universal class-wide interventions at the base of the pyramid. Tier 2 is identified as targeted intervention support provided to students who need support in addition to Tier 1 interventions. Finally, Tier 3 is identified as support for students who need intensive intervention in addition to Tier 1 interventions. Each tier includes specific academic and behavioral interventions and supports (Chaparro, Nese, \& McIntosh, 2015; Green et al., 2015).

Implementation of MTSS builds positive learning environments and positive school cultures resulting in a context for enhancing student learning and effective academic instruction (Horner \& Sugai, 2015). In order to better meet the needs of students with EBD in schools, the conceptual framework described in this article adds to the typical MTSS model key strategies for realizing social justice. One of the critical components to including students with EBD in socially just schools is to create relationship empowerment between adults and students.

To achieve these relationships, we suggest specific guidelines that are essential for adults and students to integrate into their practice and the use of strategies that will enhance their interactions within the MTSS model. These guidelines include the teaching of such skills and tools as social and emotional learning (SEL) and social skills training (SST), both embedded within the context of positive behavior intervention and supports (Durlak, Domitrovich, Weissberg, \& Gullotta, 2015; Durlak, Weissberg, Dydmnicki, Taylor, \& Schellinger, 2011). Implementing these within the tiered systems will support student academic, behavioral, and social-emotional achievement. Figure 2 shows how these programs fit into the MTSS model from a social justice perspective when implemented by educators acting as social justice allies. In the following sections, examples of the components of social justice, positive behavior interventions and supports, and, social-emotional learning within the MTSS are 
provided.

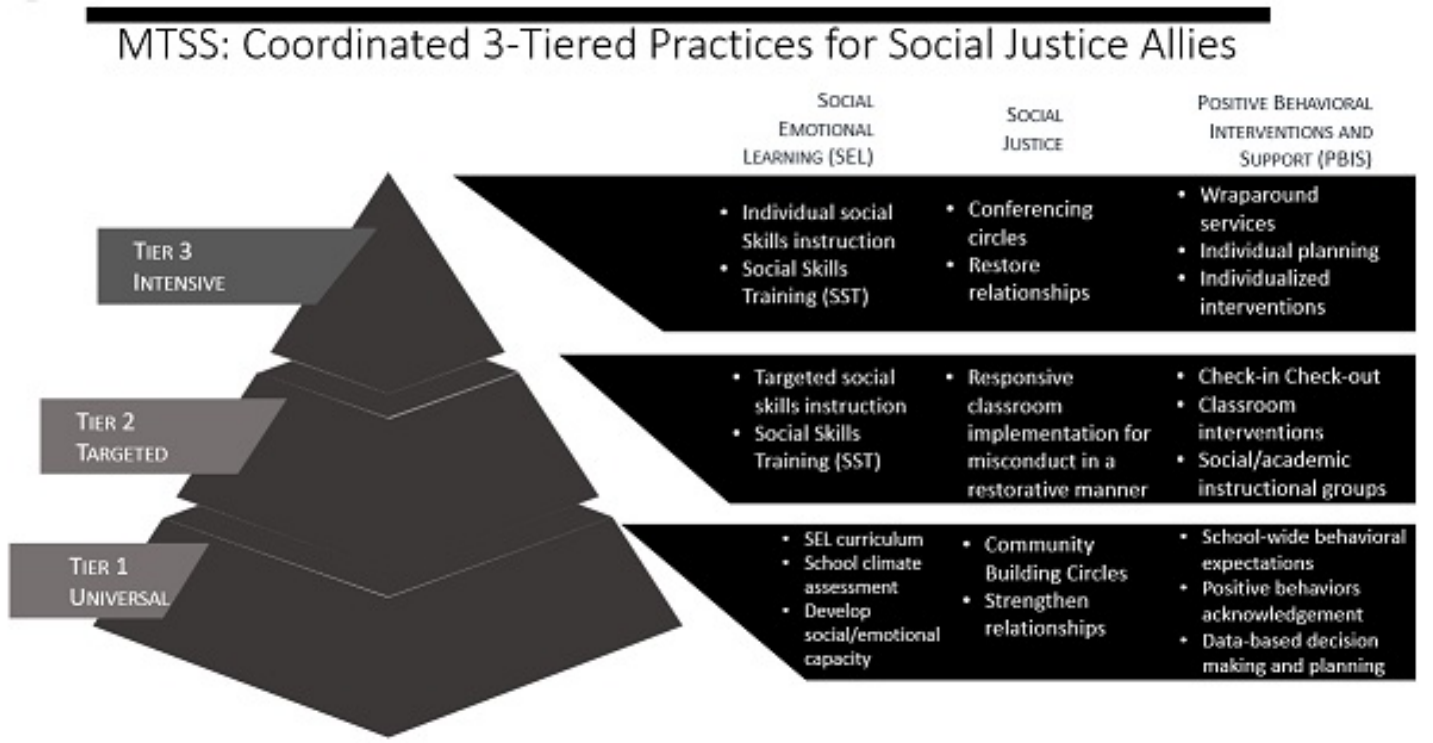

Figure 2. Components of the MTSS Three-tiered Practices for Social Justice Allies

\subsection{Social Justice}

Students who need specific support in behavior and social-emotional areas can fluidly move up and down through the layered tiers for various levels of teaching intensity, and social justice allies can plan successful practice opportunities that meet those students' skill level. Educators are called upon to do their part in attributing a social justice perspective when taking action regarding the diversity in schools, separating the advantaged from disadvantaged, and the persistent disparities in learning processes. Tier 1 of universal interventions is essential on a school-wide level to ensure that students with EBD are included amongst the membership within the student body rather than in a marginalized group. Community Building Circles are one example of a tiered-intervention approach that (e.g., https://www.edutopia.org/article/circling-community-building) provides a foundation for social justice and inclusion within school roles. They create a sense of belonging to a school where discipline is part of strengthening relationships, rather than exclusion from group membership. Teachers using a social justice perspective avoid the condemnation of a student on personal merit and instead recognize the opportunity to teach a missing skill. Addressing students categorized as EBD with the attitude that a student needs a skill in the social arena for school functioning, educators can take the opportunity to teach and/or reinforce a student encountering a problem with the skill necessary for their success. This position of not seeing the student as the problem, allows solutions to build within positive relationships and lead to learning environments in schools that are socially just and equitable. This approach establishes an expectation of success for all students and for students with EBD who are nonresponsive to this Tier 1 intervention, a Tier 2 support can be provided within the framework or as a stand-alone. An example in Tier 2 support for a student who is nonresponsive to community building circles, is the practice of restorative justice. Restorative Justice is also a practice of building relationships and demonstrating respectfulness to all students and adults within the learning environment. When a student offends the rules and causes harm to someone else, this approach is directed at repairing the harm and hopefully the relationship (Gregory, Huang, Anyon, Greer, \& Downing, 2018). There can be a small percentage of students who are nonresponsive to Tier 2 supports and need more intensive Tier 3 supports (Horner, Sugai, \& Anderson, 2010). In the model we suggest that social justice allies perform an in-depth examination of the particular needs of the students before removing them into isolated intensive practices of Tier 3. Small changes that target support using adaptations to the Tier 2 intervention protocol can be made and tailoring of a program to be better aligned with student needs. There are a number of ways researchers have begun to make these adaptations to increase the effectiveness and to save the need for added resources while still maintaining the feasibility and efficiency of Tier 2 supports (See Kilgus, Fallon, \& Feinberg, 2016; Fuchs, Fuchs, \& Malone, 2017; Majeika et al., 2019).

Students and families who previously experienced marginalization by educators imposing stricter rules on the student's behavior are part of the planning for a school climate based on teaching behavioral skills that demonstrate respect, care, and appreciation of one another. Social justice can occur when students and their parents are part of the 
vital educational processes (Dei, James, Karumancherry, James-Wilson, \& Zine, 2000; Riley \& Rustique-Forrester, 2002). The essential component of Family, School, and Community Partnering in the MTSS model serve as a perfect vehicle of social justice progression.

The complexities of how students labeled as EBD initially acquired behaviors leading to their referral to determine the need for special education services can create a sense of responsiveness by educators, which can also enhance educator/student relationships (Shields, 2004). The research literature confirms that if the educator responsiveness increases communication and dialogue with students, parents, and colleagues, positive school climate, student success, and achievement follow (Brown-Chidsey \& Steege, 2005; Kose, 2011, Wilson \& Horsford, 2014).

Two other MTSS evidence-based practices that positively affect the academic, behavioral and social achievement of students with EBD are Social-Emotional Learning (SEL) programs and Social Skills Training (SST) programs. Both SEL and SST program interventions for students with EBD focus on outcomes related to social competence; "the ability to initiate and sustain positive relationships and to accomplish a wide range of social tasks" (Wiley \& Siperstein, 2015, p. 213). SEL interventions typically target underlying cognitive and emotional processes associated with social competence whereas SST targets changing observable and measurable behaviors that lead to social success. Both of these interventions can be used within the MTSS tiered system and to varying intensities, depending on student need.

\subsection{Social-Emotional Learning}

Table 1. Selected Tier 1 Evidence-based SEL Programs Based on Evidence-Based and SAFE Criteria

\begin{tabular}{|c|c|c|c|c|}
\hline Program Title & Program Focus & Grade Range & Program Components & Contact Information \\
\hline Open Circle & $\begin{array}{l}\text { Recognizing and managing } \\
\text { emotions, empathy, positive } \\
\text { relationships and problem- } \\
\text { solving }\end{array}$ & $\begin{array}{l}\text { K-5; separate } \\
\text { lessons for each } \\
\text { grade }\end{array}$ & $\begin{array}{l}\text { - Year-long; } 32 \text { lessons; } 15 \text { minutes } \\
\text { per lesson } \\
\text {-Family engagement } \\
\text { - Instructional strategies: discussion, } \\
\text { visual displays, skill practice }\end{array}$ & http://www.open-circle.org/ \\
\hline Positive Action & $\begin{array}{l}\text { Self-concept, personal } \\
\text { responsibility for your body and } \\
\text { mind, managing yourself } \\
\text { responsibly, getting along with } \\
\text { others, self-honesty, and } \\
\text { continual self-improvement }\end{array}$ & $\begin{array}{l}\text { PreK-12; separate } \\
\text { lessons for each } \\
\text { grade through grade } \\
8 ; 4 \text { themed kits for } \\
\text { grades 9-12 }\end{array}$ & $\begin{array}{l}\text {-35 weeks; } 4 \text { lessons/week; } 15 \\
\text { minutes per lesson } \\
\text {-high focus on character, mindset, and } \\
\text { emotional processes } \\
\text {-family engagement } \\
\text {-structured activities for community } \\
\text { engagement } \\
\text {-Instructional strategies: discussion, } \\
\text { visual displays, SEL tools/handouts, } \\
\text { didactic instruction, books/stories }\end{array}$ & $\begin{array}{l}\text { https://www.positiveaction. } \\
\text { net// }\end{array}$ \\
\hline $\begin{array}{l}\text { Social Decision } \\
\text { Making/ } \\
\text { Problem } \\
\text { Solving } \\
\text { Program }\end{array}$ & $\begin{array}{l}\text { Listening, following directions, } \\
\text { identifying feelings, emotion } \\
\text { regulation, self-control, personal } \\
\text { and social awareness, social } \\
\text { problem solving/ } \\
\text { decision making, teamwork, } \\
\text { positive peer relationships }\end{array}$ & $\begin{array}{l}\text { K-8; separate } \\
\text { lessons for each } \\
\text { grade }\end{array}$ & $\begin{array}{l}\text {-30 lessons; teachers decide how } \\
\text { much time to spend on each topic } \\
\text {-family engagement } \\
\text {-Instructional strategies: discussion, } \\
\text { visual displays, SEL tools/handouts, } \\
\text { didactic instruction }\end{array}$ & $\begin{array}{l}\text { http://ubhc.rutgers.edu/sdm/ } \\
\text { index.html }\end{array}$ \\
\hline $\begin{array}{l}\text { Second Step } \\
\text { Program }\end{array}$ & $\begin{array}{l}\text { Skills for learning, empathy, } \\
\text { emotion management, and } \\
\text { problem- solving }\end{array}$ & $\begin{array}{l}\text { PreK-8; separate } \\
\text { lessons for each } \\
\text { grade }\end{array}$ & $\begin{array}{l}-22-25 \text { weeks; } 1-5 \text { lessons per week; } \\
20-45 \text { minutes per lesson; } 5-10 \\
\text { minutes per follow-through activity } \\
\text {-High focus on conflict resolution and } \\
\text { cognitive regulation } \\
\text {-Instructional strategies: Songs, } \\
\text { kinesthetic activities, games, writing, } \\
\text { video }\end{array}$ & $\begin{array}{l}\text { http://www.cfchildren.org/s } \\
\text { econd-step }\end{array}$ \\
\hline
\end{tabular}

(Based on information from CASEL, 2019 and Jones, et al., 2017) 
SEL is a process through which students and educators understand and manage social, emotional, behavioral, and character skills in order to learn how to show empathy, establish positive relationships and demonstrate citizenship (CASEL, 2019; Jones et al., 2017). SEL programs were found to be effective with students with EBD as Tier 1 interventions (Durlak et al., 2015). The most effective SEL programs include evidence-based components identified by the acronym SAFE, designating procedures for maximum impact on academic, behavioral, and social achievement. The $\mathrm{S}$ in SAFE stands for the use of a step-by-step teaching approach; the A identifies that the program interventions include active forms of learning; the F substantiates that there is focused and sufficient time on skill development; and the $\mathrm{E}$ ensure that the program interventions adhere to explicit learning goals (Zmuda \& Bradshaw, 2013). Effective SEL programs and interventions are based on targeted competencies that include: self-awareness, self-management, social awareness, relationship skills, and responsible decision-making (CASEL, 2017). Table 1 showcases several leading SEL programs that promote inclusive socially just school settings. The programs described in Table 1 were chosen based on the fact that they meet the criteria for evidence-based practices and the SAFE procedures described earlier.

\subsection{Social Skills Training}

Table 2. Tier 2 Evidence-based SST Intervention Programs

\begin{tabular}{|c|c|c|c|c|}
\hline Program Title & Program Focus & Grade Range & Program Components & Contact Information \\
\hline Coping Power Program & $\begin{array}{l}\text { - Social and emotional } \\
\text { skills for successful } \\
\text { transition from } \\
\text { elementary to middle } \\
\text { school: goal setting, } \\
\text { emotional awareness, } \\
\text { coping with negative } \\
\text { feelings and situations, } \\
\text { relaxation techniques, } \\
\text { study skills, and refusal } \\
\text { skills }\end{array}$ & $\begin{array}{l}\text { Upper elementary to } \\
\text { middle school }\end{array}$ & $\begin{array}{l}\text {-15-18 months; } 34,50 \text {-minute group } \\
\text { sessions; also has individual sessions; } \\
\text { - cognitive-behavioral child sessions: } \\
\text { goal setting, anger management, } \\
\text { social skills, organization and study } \\
\text { skills, ability to resist peer pressure, } \\
\text { entry into positive peer groups, } \\
\text {-parent component has sessions that } \\
\text { include training in behavior } \\
\text { management strategies }\end{array}$ & $\begin{array}{l}\text { http://www.copingpower } \\
\text { com/ } \\
\text { Box } 870348 \\
\text { The University of } \\
\text { Alabama } \\
\text { Tuscaloosa, AL } 35487 \\
\text { Phone: (205) 348-3535 } \\
\text { Fax: (205) 348-3526 }\end{array}$ \\
\hline $\begin{array}{l}\text { Early Risers 'Skills for } \\
\text { Success' Program }\end{array}$ & $\begin{array}{l}\text {-Targets students who } \\
\text { have been exposed to } \\
\text { violence and who are at } \\
\text { high risk for } \\
\text { development of conduct } \\
\text { problems; } \\
\text {-Focus is on improving } \\
\text { academic and social } \\
\text { skills and intervening in } \\
\text { the family environment }\end{array}$ & $1^{\text {st }}-4^{\text {th }}$ grade & $\begin{array}{l}\text {-6-week summer school program; } \\
\text { ongoing support during the school } \\
\text { year for the child and their family; the } \\
\text { program is coordinated by a family } \\
\text { advocate; } \\
\text {-in school lessons for children; } 5 \\
\text { parent meetings throughout the school } \\
\text { year with activities for the children; } \\
\text {-competence domains: academic } \\
\text { competence, behavioral } \\
\text { self-regulation, social competence, } \\
\text { parent investment in their child }\end{array}$ & $\begin{array}{l}\text { Gerald J. August, Ph.D. } \\
\text { Division of Child and } \\
\text { Adolescent Psychiatry } \\
\text { 2450 Riverside Avenue, } \\
\text { F256/2B West } \\
\text { Minneapolis, MN } \\
\text { 55454-1495 } \\
\text { 612-273-9711 (phone) } \\
\text { 612-273-9779 (fax) } \\
\text { Augus001@umn.edu }\end{array}$ \\
\hline $\begin{array}{l}\text { Incredible Years } \\
\text { Programs }\end{array}$ & $\begin{array}{l}\text {-Manage anger, solve } \\
\text { problems, getting along } \\
\text { with friends, emotional } \\
\text { awareness; promote } \\
\text { academic emotional and } \\
\text { social competence; } \\
\text { prevent, reduce and treat } \\
\text { emotional and behavioral } \\
\text { problems }\end{array}$ & PK-6 & $\begin{array}{l}\text {-20-30 minute lessons for school-age } \\
\text { children; } \\
\text {-child treatment program available to } \\
\text { be used by counselors and therapists; } \\
\text {-parent and teacher training } \\
\text { components are included } \\
\text {-Instructional strategies: videos, } \\
\text { discussion }\end{array}$ & $\begin{array}{l}14118^{\text {th }} \text { Avenue West } \\
\text { Seattle, WA } 98119 \\
(206) 285-7565 \\
\text { http://www.incredibleye } \\
\underline{\text { ars.com/ }}\end{array}$ \\
\hline
\end{tabular}

(Based on information from Wiley \& Siperstein, 2015) 
Beginning with early preventative interventions with school-wide Tier 1, SST programs can be some of the most potent work a social justice ally can promote to keep students in inclusive settings as part of the school student body. Keeping students with EBD with their peers and including them in supports such as community building, relationship strengthening, and social-emotional understanding allows them opportunities for authentic practice of skills taught.

While there were no Tier 2 or Tier 3 SST programs that met evidence based-practice criteria for students with EBD, there were several promising ones (Wiley \& Siperstein, 2015). Table 2 provides information about three promising SST programs that resulted in improved social competence for students with EBD when implemented as Tier 2 interventions. These promising interventions for students with EBD involved combinations of modeling, coaching, practice, feedback, and other methods derived from applied behavior analysis (Lane, Kalber, \& Menzies, 2013; Scott, 2017; Wiley \& Siperstein, 2015). These interventions support the notion that the key to effective SST interventions for students with EBD is the identification of individual needs related to the function of the behavior, competing behaviors, and acquisition and performance strengths and needs (e.g., cannot do vs. will not do).

Reviewing the SST programs requires consideration of the individual needs of students with EBD and what is likely to work with them. What seems to be most evident when considering the promotion of inclusive, socially just school environments for students with EBD is the need for MTSS to address their unique targeted and intensive academic, behavioral and social-emotional learning needs. High-quality, evidence-based practice Tier 1 SEL interventions, and Positive Behavior Interventions and Supports (PBIS) combined with promising practice Tier 2 SST interventions provide ideas for meeting these needs. It is the combination of these interventions that will result in the most significant impact on achievement (Lane, Oakes, \& Menzies, 2014; Wiley \& Siperstein, 2015).

\subsection{Positive Behavior Interventions and Supports}

PBIS is the designated interventions and supports found within the tiers of the MTSS. The core features of PBIS as outlined by McIntosh, Girvan, Horner, Smolkowski and Sugai, (2014) are:

1) Define and teach a small set of school-wide behavior expectations to all students (e.g., through interventions such as SEL, SST),

2) Establish a regular pattern whereby all adults recognize, reinforce, and reward displayed desired student behavior,

3) Minimize the likelihood that problem behavior will be rewarded,

4) Provide multiple tiers of intervention intensity to meet the needs of all students (i.e., MTSS), and

5) Engage in the collection of data for decision-making.

Addressing schoolwide PBIS using authority to balance the power-sharing with others, not control over, will result in creating productive, positive, safe and orderly learning environments. In a socially just school, how teachers and administrators use authority to create disciplinary and instructional procedures that minimize power, relationships are key! Smyth (2004) referred to the balanced power concept in his description of a socially just school (e.g., enact democratic forms of practice). McIntosh et al. (2014) said that the same effect resulted in schools with the implementation of the PBIS core principles.

Social justice allies learn to analyze the discipline data collected through PBIS implementation and instead of blaming students for breaking rules and not showing acceptable social skills, they clarify and reteach rules, reinforce when desired behaviors are displayed, and reward through the support system. In these ways, social justice allies in schools promote student thinking and analyze problem situations using dignity-preserving skills. In teaching and reinforcing opportunities where social skills can address conflicts between students, allies support the power balance amongst peers and ready students for the potential human conflicts that are inevitable. Instead of the strict adherence to a list of policies and rules that aim to constrain student behavior to a predetermined set of reactions, social justice allies use skills to defuse situations and appeal to relationship cultivation.

The implementation of PBIS involves social change based in the impact of creating a welcoming campus climate, purposeful positive interactions with students by educators, using data to drive instructional equity, regardless of the students' presentation of social and behavioral challenges. The positive support system nurtured using PBIS allows for social and instructional influences to ripple school-wide. In schools that employ a PBIS framework, all educators are champions for students with EBD, not just the special education teachers; all educators school-wide strive to have positive interactions with all students including those identified with EBD. To sustain this type of environment requires support from district administrators, support for training, implementation, and maintenance on all levels. 


\section{Conclusion}

Students with EBD experience marginalization in schools at a higher rate than their peers without disabilities. There is evidence in both research and practice that educators who practice Social Justice with an MTSS model can overcome the power imbalance that attributes to the disparities of educational access by students with EBD. The importance of students with EBD to be immersed in the learning environment, included with their peer group, and to access quality academic instruction that will allow them to move through their educational experience toward graduation is the focus of the suggested model.

This article provided suggestions of interventions in a tiered system of support for educators to ensure equity and social justice in inclusive schools for students with EBD. The most evident characteristic of socially just schools is that adults and students exercise a balanced use of power with each other. Ideas for creating socially just schools were shared. These ideas included articulating purpose and how these ideas intersect with a multi-component MTSS framework that influences equity in school settings. Evidence-based practice Tier 1 SEL programs and promising practice Tier 2 SST programs for the development of social competence in students with EBD were described. Development of social competence for students with EBD was found to promote academic, behavioral and social-emotional achievement and success in schools. Implementing these interventions while being social justice allies in socially just schools offer the best opportunity for students with EBD to receive an equitable and socially just education in schools thereby achieving social justice regarding their civil right to a FAPE.

\section{References}

Artiles, A. J., Bal, A., \& Thorius, K. K. (2010). Back to the future: A critique of response to intervention's social just views. Theory Into Practice, 49(4), 250-257. https://doi.org/10.1080/00405841.2010.510447

Avant, D. W. (2016). Using response to intervention/multi-tiered systems of supports to promote social justice in schools. Journal for Multicultural Education, 10(4), 507-520. https://doi.org/10.1108/JME-06-2015-0019

Banks, T., \& Obiakor, F. (2015). Culturally responsive positive behavior supports: Considerations for practice. Journal of Education and Training Studies, 3(2), 83-90. https://doi.org/10.11114/jets.v3i2.636

Brobbey, G. (2018). Punishing the vulnerable: Exploring suspension rates for students with learning disabilities. Intervention in School and Clinic, 53(4), 216-219. https://doi.org/10.1177/1053451217712953

Brown-Chidsey, R., \& Steege, M. W. (2005). Response to Intervention: Principles and strategies for effective practice. NY: Guilford Press. Collaborative for Academic, Social, and Emotional Learning (CASEL, 2019). SEL in Action. Retrieved from https://casel.org/in-action/

Collaborative for Academic, Social, and Emotional Learning (CASEL, 2017). Social and Emotional Learning (SEL) Competencies. Retrieved from http://www.casel.org/wp-content/uploads/2017/01/Competencies.pdf

Colorado Department of Education. (CDE, 2015). Multi-Tiered System of Supports. Retrieved from www.cde.state.co.us/mtss

Cordingley, P. (2015). The contribution of research to teachers' professional learning and development. Oxford Review of Education, 41(2), 234-252. https://doi.org/10.1080/03054985.2015.1020105

Dei, G., James, I. M., Karumancherry, L. L., James-Wilson, S., \& Zine, J. (2000). Removing the margins: The challenges and possibilities of inclusive school. Toronto: Canadian Scholar's Press.

Durlak, J. A., Domitrovich, C. E., Weissberg, R. P., \& Gullotta, T. P. (Eds.) (2015). Handbook of social and emotional learning: Research and practice. New York, NY: The Guilford Press.

Durlak, J. A., Weissberg, R. P., Dymnicki, A. B., Taylor, R. D., \& Schellinger, K.B. (2011). The impact of enhancing students' social and emotional learning: A meta-analysis of school-based universal interventions. Child Development, 82(1), 405-432. https://doi.org/10.1111/j.1467-8624.2010.01564.x

Education Week Research Center Analysis of IDEA (2018). 39 $9^{\text {th }}$ annual report to Congress on the implementation with Disabilities Education Act.

Ennis, R., \& Katsiyannis, A. (2018). Avoiding unwarranted segregation of students with behavioral needs: Lessons learned. Intervention in School and Clinic, 53(4), 212-215. https://doi.org/10.1177/1053451217712954

Freeman, J., Simonsen, B., McCoach, D. B., Sugai, G. M., Lombardi, A., \& Horner, R. (2015). An analysis of the relationship between implementation of school-wide positive behavior interventions and support and high 
school dropout rates. High School Journal, 98, 290-315. https://doi.org/10.1353/hsj.2015.0009

Fried, J., \& Harper, R. (2017). Learning everywhere on campus: Teaching strategies for student affairs professionals. New York: Routledge. https://doi.org/10.4324/9781315205809

Fuchs, L. S., Fuchs, D., \& Malone, A. S. (2017). The taxonomy of intervention intensity. TEACHING Exceptional Children, 50, 35-43. https://doi.org/10.1177/0040059917703962

Green, A. L., Nese, R. N. T., McIntosh, K., Nishioka, V., Eliason, B., \& Canizal, D. A. (2015). Key elements of policies to address disproportionality within SWPBIS: A guide for district and school teams. OSEP Technical Assistance Center on Positive Behavioral Interventions and Supports. Retrieved from http://www.pbis.org/school/equity-pbis

Gregory, A., Huang, F. L., Anyon, Y., Greer, E., \& Downing, B. (2018). An examination of restorative interventions and racial equity in out-of-school suspensions. School Psychology Review, 47(2), 167-182. https://doi.org/10.17105/SPR-2017-0073.V47-2

Hattie, J., \& Anderman, E. M. (2013). International guide to student achievement. New York, NY: Routledge.

Hong, J., Greene, B., Roberson, R., Francis, D., \& Keenan, L. (2018). Variations in pre-service teachers' career exploration and commitment to teaching. Teacher Development, 22(3), 408-426. https://doi.org/10.1080/13664530.2017.1358661

Horner, R. H., \& Sugai, G. M., \& Anderson, C. M. (2010). Examining the evidence base for schoolwide positive behavior support. Focus on Exceptional Children, 42(8), 1. https://doi.org/10.17161/foec.v42i8.6906

Horner, R. H., \& Sugai, G. M. (2015). School-wide PBIS: An example of applied behavior analysis implemented at a scale of social importance. Behavioral Analysis in Practice, 8, 80-85. https://doi.org/10.1007/s40617-015-0045-4

Horner, R. H., Sugai, G. M., \& Lewis, T. (2015). Is school-wide positive behavior support an evidence-based practice? Retrieved from http://www.pbis.org/research

Individuals with Disabilities Education Act, 20 U.S.C. § 1400 (IDEA, 2004).

Jones, S., Brush, K., Bailey, R., Brion-Meisels, G., McIntyre, J., Kahn, J., Nelson, B., \& Stickle, L. (2017). Navigating SEL from the inside out: Looking inside \& across 25 leading SEL programs: A practical resource for schools and OST providers. Boston, MA: Harvard Graduate School of Education. Retrieved from $\mathrm{http} / / / \mathrm{www}$.wallacefoundation.org/knowledge-center/Documents/Navigating-Social-and-Emotional-Learning-fr om-the-Inside-Out.pdf

Kilgus, S. P., Fallon, L. M., \& Feinberg, A. B. (2016). Function-based modification of check-in/check-out to influence escape-maintained behavior. Journal of Applied School Psychology, 32, 24-45. https://doi.org/10.1080/15377903.2015.1084965

Klinger, J., \& Edwards, P. (2006). Cultural considerations with response to intervention models. Reading Research Quarterly, 4l(1), 108-177. https://doi.org/10.1598/RRQ.41.1.6

Kose, B. W. (2011). Developing a transformative school vision: Lessons from peer-nominated principals. Education and Urban Society, 43(2), 119-136. https://doi.org/10.1177/0013124510380231

Lane, K. L., Kalberg, J. R., \& Menzies, H. M. (2013). Developing schoolwide programs to prevent and manage problem behaviors: A step-by-step approach. New York, NY: The Guilford Press.

Lane, K. L., Oakes, W. P., \& Menzies, H. M. (2014). Comprehensive, integrated three-tiered models of prevention: Why does my school - and district - need an integrated approach to meet students' academic, behavioral and social needs? Preventing School Failure, 58(3), 121-128. https://doi.org/10.1080/1045988X.2014.893977

Majeika, C. E., Van Camp, A., Kern, L., Wehby, J. H., Commisso, C. E., \& Gaier, K. (2019). An evaluation of adaptations made to Check-In Check-Out. Journal of Positive Behavior Interventions, 1-13. https://doi.org/10.1177/1098300719860131

McDermott, V. (2017). We must say no to the status quo: Educators as allies in the battle for social justice. Thousand Oaks, CA: Corwin, A Sage Co. https://doi.org/10.4135/9781506345994

McIntosh, K., \& Goodman, S. (2016). Integrated multi-tiered systems of support: Blending RTI and PBIS. New York, NY: The Guilford Press. 
McIntosh, K., Girvan, E. J., Horner, R. H., Smolkowski, K., \& Sugai, G. (2014). Recommendations for addressing discipline disproportionality in education. OSEP Technical Assistance Center on Positive Behavioral Interventions and Supports.

McIntosh, K., Girvan, E. J., Horner, R. H., Smolkowski, K., \& Sugai, G. (2018). A 5-point intervention approach for enhancing equity in school discipline. OSEP Center on Positive Behavioral Interventions and Supports. Retrieved from https://www.pbis.org/Common/Cms/files/pbisresources/A\%205-Point\%20Intervention\%20\%20Approach\%20f or\%20Enhancing\%20\%20Equity\%20in\%20School\%20Discipline.pdf

McIntosh, K., Ty, S. V., Horner, R. H., \& Sugai, G. (2013). School-wide positive behavior interventions and supports and academic achievement. In J. Hattie, \& E. M. Anderman (Eds.), International guide to student achievement (pp. 146-149). NY: Routledge.

Office of Special Education and Rehabilitative Services, "Dear Colleague Letter on the Inclusion of Behavioral Supports in Individualized Education Programs" (August 1, 2016), accessed August 12, 2019, https://www2.ed.gov/policy/gen/guid/school-discipline/files/dcl-on-pbis-in-ieps--08-01-2016.pdf

Preston, A. I., Wood, C. L., \& Stecker, P. M. (2016). Response to intervention: Where it came from and where it's going. Preventing School Failure: Alternative Education for Children and Youth, 60, 173-182. https://doi.org/10.1080/1045988X.2015.1065399

Proctor, S. L., Graves, S. L., \& Esch, R. C. (2012). Assessing African American students for specific learning disabilities: The promises and perils of Response to Intervention. Journal of Negro Education, 81, 268-282. https://doi.org/10.7709/jnegroeducation.81.3.0268

Riley, E. K., \& Rustique-Forester, E. (2002). Working with disaffected students. London, England: Paul Chapman.

Santo, C. S., Ferguson, N., \& Trippel, A. (2010). Engaging urban youth through technology: The youth neighborhood mapping initiative. Journal of Planning Education and Research, 30(1), 52-65. https://doi.org/10.1177/0739456X10366427

Scott, T. M. (2017). Teaching behavior: Managing classrooms through effective instruction. Thousand Oaks, CA.

Shields, P. M. (2004). Classical pragmatism: Engaging practitioner experience. Administration \& Society, 36(3), 351-361. https://doi.org/10.1177/0095399704265323

Smolkowski, K., Girvan, E. J., McIntosh, K., Nese, R. N. T., \& Horner, R. H. (2016). Vulnerable decision points for disproportionate office discipline referrals: Comparisons of discipline for African American and White elementary school students. Behavioral Disorders, 41, 178-195. https://doi.org/10.17988/bedi-41-04-178-195.1

Smyth, J. (2004). Social capital and the 'socially just school.' British Journal of Sociology of Education, 25(1), 19-34. https://doi.org/10.1080/0142569032000155917

Turse, K. A., \& Albrecht, S. F. (2015). The ABCs of RTI: An introduction to the building blocks of Response to Intervention. Preventing School Failure: Alternative Education for Children and Youth, 59(2), 83-89. https://doi.org/10.1080/1045988X.2013.837813

UNESCO (1994). The Salamanca statement and framework for action on special needs education. World Conference on Special Needs Education: Access and Quality, Salamanca, Spain.

United Nations (1948). Universal declaration of human rights: General Assembly Resolution 217A. Paris, France: United Nations General Assembly.

U.S. Department of Education. (2016 a). $38^{\text {th }}$ annual report to Congress on the implementation of the Individuals with Disabilities Education Act, 2016. Washington, DC: Author. Retrieved from https://www2.ed.gov/about/reports/annual/osep/2016/parts-b-c/38th-arc-for-idea.pdf

U. S. Department of Education. (2016 b). School climate and discipline: Know the data. Retrieved from https://www2.ed.gov/policy/gen/guid/school-discipline/data.html

U.S. Department of Education Office for Civil Rights (2016). Civil rights data collection: First look report. Retrieved from https://www2.ed.gov/about/offices/list/ocr/data.html

Wiley, A. L., \& Siperstein, G. N. (2015). SEL for students with high-incidence disabilities. In J. A. Durlak, C. E. Domitrovich, R. P. Weissberg, \& T. P. Gullotta (Eds.), Handbook of social and emotional learning: Research and practice (pp. 213-228). New York, NY: The Guilford Press. 
Wilson, C. M., \& Horsford, S. D. (Eds). (2014). Advancing equity and achievement in America's diverse schools: Inclusive theories, policies, and practices. NY: Routledge.

Zirkel, P. (2015). Special Education law: Illustrative basics and nuances of key IDEA components. Teacher Education and Special Education, 38(4), 263-275. https://doi.org/10.1177/0888406415575377

Zmuda, J., \& Bradshaw, C. P. (2013). Social and emotional learning and academic achievement. In J. Hattie, \& E. M. Anderman (Eds.), International guide to student achievement (pp. 173-176). NY: Routledge. 